\title{
Modern methods of monitoring and assessing the current status of athletes-combatants in real time
}

\author{
Yaroslavna Puhach' \\ Valeriy Druz ${ }^{1}$ \\ Andriy Yefremenko ${ }^{1}$ \\ Valeriy Revenko ${ }^{2}$ \\ Mykola Galashko' \\ Vjacheslav Shutieiev' \\ Tetyana Nizhevskaya ${ }^{3}$ \\ Valery Miroshnichenko ${ }^{1}$
}

\author{
${ }^{1}$ Kharkiv State Academy of Physical Culture, Kharkiv, Ukraine \\ ${ }^{2}$ Kharkiv National University of Internal Affairs, Kharkiv, Ukraine \\ ${ }^{3} \mathrm{H}$. S. Skovoroda Kharkiv National Pedagogical University, \\ Kharkiv, Ukraine
}

Purpose: to establish the most effective methods of monitoring and evaluating the current status of athletes, and on the basis of this, develop methods for remote monitoring of the current state of martial arts in the process of conducting a duel.

Materials \& Methods: videotapes of competitive fights of athletes participating in Ukrainian championships, world championships, and Olympic Games were used in the research. The methods used are: "high-speed video filming" a biomechanical analysis of the kinematic displacements of the total center of mass of an athlete and individual bio-kinematic parts of the body, followed by the determination of the dynamic efforts that ensure their movement, as well as the statistical stress that determines the availability of these efforts.

Results \& Conclusions: the use of modern technical video recording tools and computer equipment with appropriate programs for processing video sequences of performed movements and on the basis of established regularities of the flow of biodynamic efforts of competitive movements of martial sportsmen opens up broad possibilities for developing methods for remote contactless monitoring of the current status of athletes.

Keywords: semantic spaces, biomechanical analysis, dynamic force.

\section{Introduction}

Currently, there are no objective methods for contactless remote assessment of the current status of athletes leading the fight at sports arenas. This is complicated by the fact that their physical activity takes place in a situational situation and is unpredictable, the actions performed are acyclic and extremely varied both in the arsenal of specific features of movements in a particular form of martial arts, and in the features of their performance. All this as a whole creates great difficulties not only in monitoring the current state, but also in the subsequent analysis of its implementation. The emergence of modern video technology allows the analysis of the actions of athletes, but the assessment of the measure of fatigue on the results of video shooting is not currently carried out, which is an important unresolved task

Its solution is of interest for almost any sport. This problem is solved in cyclic sports, based on the use of the method of "statistical layering" of performed cycles of movements.

His made it possible to observe quite clearly the dynamics of their frequency-amplitude oscillations, which was successfully carried out in the works on the study of the sprint run by A. Yefremenko [1]. In the works of Van Sin Na [4], G. P. Artemyeva [5], M. N. Galashko [6], Ya. I. Puhach [8] established a characteristic feature of the static force change at the angle of bend between the biokinematic links "thigh-shin", "shoulder-forearm" both in the mode of development of the effort to be overcome and in the case of repayment of the impulse of force. In these studies, for the first time, the dependence of the increase in the effort on the angle of extension of the biokinematic links was established, which is characterized as the quantity $\partial \mathrm{F} / \partial \varphi$. This characteristic is described in polar coordinates by a logarithmic spiral, which clearly gives a graphic representation of its changes during fatigue. This characteristic allowed $A$. N. lefremenko to find a strictly determined relationship between the kinematic characteristics of the movement of the biological links of the limb in a smooth run at short distances, dynamic efforts, which are provided by their movements, and static voltage, which preserves the working posture of the athlete's body when moving it in the race. Based on the regularity of the behavior of the $\partial F / \partial \varphi$ characteristic and its changes during the run, he was the first to establish a feature of reducing the energy potential during the passage of a distance, which is that the kinetic energy consumption of body mass movement over the distance covered was less than the total loss.

The calculations were carried out on the basis of the analysis of high-speed video filming of the run of athletes of various ranks [9].

The results of these studies formed the basis for a modification of the method of remote assessment of the current status of an athlete-combatant during a duel, in determining its energy costs for conducting receptions against an opponent; protection from enemy attacks; passive actions when preparing your attack or waiting for the actions of the enemy This technique and its use in the conducted research on the example of combat sambo is presented for the first time.

Connection of research with scientific programs, plans, themes. The presented materials of the research carried out in accordance with the Consolidated plan of research in the field of physical culture and sports for the period 20112015 on the topic "Theoretical and methodological foundations of improving the training process and competitive activity in the structure of long-term training of athletes", state registration number 0111 U001168.

Purpose of the study: establish the most effective
Puhach, Y., Druz, V., Yefremenko, A., Revenko, V., Galashko M., Shutieiev, V., Nizhevskaya, T. \& Miroshnichenko, V. (2019), "Modern methods of monitoring and assessing the current status of athletes-combatants in real time", Slobozans "kij naukovosportivnij visnik, No. 3(71), pp. 54-60, doi:10.15391/snsv.2019-
3.010 


\section{СЛОБОЖАНСЬКИЙ НАУКОВО-СПОРТИВНИЙ ВІСНИК}

methods of monitoring and assessing the current status of athletes, carried out in real time in the process of conducting the fight.

Objectives of the study:

1. To analyze the scientific and methodological literature on the existing methods of control carried out remotely in real time for the current state of the athletes, or the "human operator" who performs his work under special or extreme conditions.

2. To establish the relationship between the complexity of the goal; tasks aimed at achieving it, and the possibilities of existing methods to solve them.

3. Based on the analysis carried out, develop a method that has the necessary solvability to achieve the goal.

4. To test the method obtained.

\section{Material and Methods of the research}

Materials: data of video fights performances of athletes.

Research methods: analysis and synthesis of scientific and methodological literature; biomechanical video processing; methods of mathematical approximation of the kinematic displacement of the centers of mass of individual parts of the body and the general center of body mass; graphical presentation of research results in indicative semantic spaces.

\section{Results of the research}

Remote monitoring of the current state of a person who is not burdened with any hardware equipment has been unresolved for a long time, as there were no integral methods for assessing the current state. This issue was most acute in transport systems, in aviation and space medicine, engineering psychology [17]. The first, rather effective solution to this problem was found in the development of methods for monitoring the control of the aircraft [21]. It was based on the control over the implementation of the final result of professional work in the management of the pilot of the aircraft by "aircraft control stick". Depending on the current state of the pilot, his accuracy of the flight training program by the aircraft control stick movement varied.

The peculiarity of the construction of this method was that control over the state of the contractor is carried out by a qualitative assessment of the implementation of the final result of a given professional activity. The observed executor was not burdened with any devices while monitoring the course of his functional state.

This method of control in all respects corresponds to its application in the practice of monitoring the action of an athlete-combatant during a sporting match as the type of his professional activity and evaluation of its result by external observation. However, its use to assess the interaction of two athletes is insufficient, since in the first case the error in the control of the aircraft by the pilot is completely predictable on the result of the behavior of the aircraft, and there is always direct contact of the pilot through the aircraft control stick and in the interaction of two opponents in single combat, this method does not allow to give a reasonable forecast of the further development of the process being conducted, as it relates to non-stationary processes.

The valuable result of applying the method described above is that it is based on an integral indicator of a person's general condition, which influences the achievement of the final result performed by the professional activity. Any deviation of the current state from its adequate standard for the work being performed entails an error in the correctness of the action being performed. An equally important result was the established pattern of the exponential growth of the allowed error with a linear dependence of the indicators of the functional state, which is an integral indicator of deviation from its "norm".

Thus, the necessary resolvability of observation becomes possible only if we take into account the integral indicator of the general functional state of a person and the indicator of the magnitude of deviation from the adequate norm of the current state. On the basis of these characteristics, a graphic construction of these relations is carried out in a special attribute semantic space with a single measure of comparable characteristics, which reflects the analytical dependence of the description of the sought pattern. As noted above, this problem was solved by A. Yefremenko when analyzing the energy consumption of the static stress of the working posture and the dynamic efforts that ensure the kinematic displacement of the center of mass of the body parts and the common center of mass in the supporting and unsupported phases of its movement in a runner at a short distance [9].

Based on the foregoing, to assess the current functional state of a martial fighter when conducting a duel, the pattern of changes in the $\partial \mathrm{F} / \partial \varphi$ characteristic was used in the plyometric mode of its manifestation in movements during the reactions with support. This is reflected in the nature of the observed static voltage changes its magnitude and duration of the flow. The process of remote monitoring was carried out by a special video camera and an appropriate program for processing the video sequence of the athlete's movements performed in real time. Systematization of the athlete's motor activity throughout the entire fight consists in the division of the performed actions into non-contact movement and contact interaction. In the time series of the athlete's movement, a continuous assessment of the change in magnitudes $\partial F / \partial \varphi$ was carried out, and against its background, an estimate of the value of $\partial F / \partial \varphi$ was carried out, which made it possible to establish the relationship between the variation of the static voltage and the dynamic force observed with it, determined by the athlete. The empirical data, on the basis of which the above stated regularities were established, are presented in tables 1-4.

Static voltage is characterized by an equal force ratio of the voltage of synergists and antagonists. The magnitude of this relationship is always equal to one. The potential energy supply providing such a ratio may vary from the permissible minimum to the maximum possible maximum. Oscillations or ripple of potential energy relative to any point; static voltage is observed within the entire range of its value. The maximum possible value of this process is observed in the middle of the range of static voltage. Depending on the intensity of static voltage and the duration of its preservation, the expenditure of potential energy occurs. The expenditure of potential energy is spent on dynamic efforts, which generates the movements of the bio-kinematic links of the body, which are to a certain extent aimed at maintaining the static position of the working posture when performing movements of professional orientation.

When measuring the static force in various angular values in any biokinematic pair, its quantitative characteristic is established. This value remains the same for both synergists and antagonists. Any motor act is accompanied as a result of changes in dynamic efforts between antagonists and syner- 


\section{SLOBOZANS'KIJ NAUKOVO-SPORTIVNIJ VISNIK}

gists. Since all the considered characteristics are expressed in the same physical quantities, their relationship represents a dimensionless quantity, which is measured within a unit, if the full range of variation of all the relationships encountered is taken as one.

Consumption of potential energy, if it is not replenished during the work, is reduced, which is regarded as fatigue. Geometrically, this can be represented as a reduction in the length of the range, which is adopted by the "conventional unit". For the actual implementation of motor activity aimed at displacing the centers of mass of the bio-kinematic links of the body and the common center of mass of the body, the absolute values of the dynamic efforts necessary to ensure the kinematics of the actions performed remain the same.

This leads to a change in the structure of static stress, manifested in a change in the working posture of an athlete, which in turn leads to changes in the speed and trajectory of movement of both the common center of mass of the whole body and of its individual kinematic links, the technique, movement is disturbed, the increase in allowed errors increases, the efficiency factor decreases power consumption. Characteristics of temporal, spatial and power indicators undergo a mismatch. If this process is not comparable with the same to the opponent, it is manifested in the superiority of one whose energy potential is higher.

Since the process of fatigue is reflected in the change in the kinematics of motion, and it is described in strictly defined analytical equations, the video monitoring performed allows us to estimate the progress of this process in real time. Its representation in dimensionless quantities in semantic space allows us to express the qualitative characteristics of the state of fatigue in quantitative terms of the observed analytical dependence.

It is almost impossible to reveal this pattern by conventional research methods, which are used when comparing various variants of relations of a measure of static voltage of its pulsating oscillation, while variations in the dynamic efforts of synergists and antagonists ensuring the execution of a motor act. Especially if this comparison is based on group average data. As an example, it is enough to consider the structure of the analysis of the variation of static voltage and dynamic efforts of synergists and antagonists in the organization of the equifinal result of the performed professional activity.

The magnitude of the possible manifestation of static force depends on the innate body type, current physical condition, level of physical fitness. In the ongoing research measurements were taken static forces. Regardless of the current state, innate data, body type, current physical condition and level of physical fitness, static stress is characterized by the fact that the relationship between the dynamometry of synergists and antagonists remains equal. All the parameters listed above lose the significance of the absolute values, and only the indication of the fluctuation of the range of the ripple boundaries of the dynamic force from the minimum value to the maximum value remains. The boundaries of this range in any case correspond to some current value of static voltage equal to one.

Since the generators of this characteristic are dynamic efforts of synergists and antagonists, their unequal relations also give a dimensionless characteristic, which varies from 0 to 1 subject to the introduction of a measure $2(\mathrm{SV}-\mathrm{S})$ or $\frac{2(\mathrm{SV}-\mathrm{A})}{\mathrm{SV}}$ where is SV - current static voltage; $\mathrm{S}$ - the mV maximum observed dynamic synergistic effort; $A$ - the minimum observed dynamic force of the antagonist, which is typical for the implementation of the action performed. In this case, the difference of the resulting static voltage oscillations is the range of its pulsating oscillation $(P)$. In this representation of the four interdependent characteristics, such a parameter as time is excluded. We are talking only about the amplitude interdependence, characteristics considered. Tables 1-4 present the data of one athlete, whose readings are reflections of the relationship between the synergist and antagonist tension at different angles $\varphi$ between the lower leg and thigh, reflecting the static stress of the working posture, in ensuring the flow of dynamic efforts of the movements performed.

Variants of this kind of relationship, depending on their mutual conditionality, can be created much more, but it is practically impossible to establish a general connection between all four characteristics in this type of analysis.

In the subsequent analysis of these data, the economy of energy consumption for each selected group of movements was evaluated, which was used to determine the optimal tactical behavior and the economy of energy consumption for conducting attacking and defensive actions. In general, the analysis of the fight was carried out to assess its initial and final energy potential, as well as the pulsation of this potential in the time of the entire fight.

With accurate information about the anthropometric characteristics of the growth-weight indicators, a similar calculation was carried out for the enemy, which later allowed to establish its energy consumption dynamics and correlation of profitability ratios in the interaction of each fragment of the fight.

The lack of previously existing video monitoring technology, appropriate software and the necessary computer equipment, as well as developed feature semantic spaces with a single measure of comparable characteristics introduced in them, reflecting the presented empirical data in an orderly

Table 1

The characteristic of the static stress of the working posture, reflecting the relationship of the pulsating dynamics of the efforts of synergists and antagonists with different angular deviations of the biokinematic elements of the "hip-shin" pair.

Data systematized by the size of the pulsating range of effortsof the synergist-antagonist when performing a motor act $\left(^{\circ}\right)$

\begin{tabular}{|c|c|c|c|c|c|c|c|c|c|}
\hline No. & $S$ & $\mathbf{A}$ & $\mathbf{P}$ & SV & No. & $\mathbf{S}$ & $\mathbf{A}$ & $\mathbf{P}$ & SV \\
\hline 1. & 100 & 20 & 20 & 90 & 17. & 120 & 60 & 60 & 90 \\
\hline 2. & 120 & 100 & 20 & 110 & 18. & 140 & 80 & 60 & 110 \\
\hline 3. & 140 & 120 & 20 & 130 & 19. & 160 & 100 & 60 & 130 \\
\hline 4. & 160 & 140 & 20 & 150 & 20. & 180 & 120 & 60 & 150 \\
\hline 5. & 180 & 160 & 20 & 170 & 21. & 100 & 20 & 60 & 60 \\
\hline 6. & 80 & 50 & 30 & 65 & 22. & 120 & 40 & 80 & 80 \\
\hline 7. & 100 & 70 & 30 & 85 & 23. & 140 & 60 & 80 & 100 \\
\hline 8. & 110 & 80 & 30 & 95 & 24. & 160 & 80 & 80 & 120 \\
\hline 9. & 120 & 90 & 30 & 105 & 25. & 180 & 100 & 80 & 140 \\
\hline 10. & 160 & 130 & 30 & 145 & 26. & 130 & 50 & 80 & 90 \\
\hline 11. & 180 & 150 & 30 & 165 & 27. & 120 & 30 & 90 & 75 \\
\hline 12. & 100 & 60 & 30 & 80 & 28. & 140 & 50 & 90 & 95 \\
\hline 13. & 120 & 80 & 40 & 100 & 29. & 150 & 60 & 90 & 105 \\
\hline 14. & 160 & 120 & 40 & 140 & 30. & 160 & 70 & 90 & 115 \\
\hline 15. & 180 & 140 & 40 & 160 & 31. & 170 & 80 & 90 & 125 \\
\hline 16. & 100 & 40 & 40 & 70 & 32. & 180 & 90 & 90 & 135 \\
\hline
\end{tabular}
ic effort; $A$ - dynamic effort of the antagonist in the frame analysis of the performed movement by the athlete, $P$ - pulsating oscillation.
Puhach, Y., Druz, V., Yefremenko, A., Revenko, V., Galashko, M. Shutieiev, V., Nizhevskaya, T. \& Miroshnichenko, V. (2019), "Modern methods of monitoring and assessing the current status of athletes-combatants in real time", Слобожанський науковоспортивний вісник, № 3(71), С. 54-60, doi:10.15391/snsv.20193.010
Puhach, Y., Druz, V., Yefremenko, A., Revenko, V., Galashko, M., Shutieiev, V., Nizhevskaya, T. \& Miroshnichenko, V. (2019) "Modern methods of monitoring and assessing the current status of athletes-combatants in real time", Slobozans 'kij naukovosportivnij visnik, No. 3(71), pp. 54-60, doi:10.15391/snsv.2019
3.010 


\section{СЛОБОЖАНСЬКИЙ НАУКОВО-СПОРТИВНИЙ ВІСНИК}

Table 3

The ratio of changes in synergistic efforts, static voltage pulsations with a constant indicator of the efforts of antagonists. The data is selected from table 1

\begin{tabular}{ccccccc}
\hline A & 80 & 80 & 80 & 80 & 80 & 80 \\
S & 100 & 110 & 120 & 140 & 160 & 170 \\
P & 20 & 30 & 40 & 60 & 80 & 90 \\
SV & 90 & 95 & 100 & 110 & 120 & 125 \\
\hline
\end{tabular}

form, while establishing the consistency of the studied characteristics of the interacting characteristics, not allowed to solve problems of the complexity.

From the analysis it follows that:

1) for comparing and commensurability of the observed interdependent relations in processes and phenomena, a unified measure of their representation in non-changeable units is necessary in order to obtain the proportion of their ratio to each other in commencement to something third, as the value of the standard of comparison. They can be the range of fluctuations of these values from its max to min; or their sum (compared values) to their current value. In this case - the opened share ratio of each part to the whole. The change of the whole remains uncertain. They are the current potential of the entire system. In this case, only the qualitative component of the whole is reflected, but not its value;

2) the stability of the occurrence of the considered ratios of the compared quantities is expressed in their constancy of manifestation, which, with their multiple layering, is reflected in the indicator "how much?".

Choosing the characteristic of any comparable value (the interval "max-min", or the value of the relationship), it is necessary to accumulate its combination, after which it came and what follows after it. "What emerged from the past", "what gave birth to the present". The constancy of statistical accumulation in the current present, as the basis of the observed indicator, and the variation around it of the past from which it arose, and the subsequent that it gave rise, gives a "structure of the constancy of the occurrence of constant relationships", which reflects its qualitative structure and the variability of the compared structure. Its universality of the emergence and transition into the next, that is, the triad "generating-existinggenerated", or "past-present-next", or "previous-presentfuture";

3) the manifestation of a statistical accumulation of "constancy of observation of the following structures of constancy of the occurrence of constant relations" is an expression of a certain self-organizing system that emerged from the generator environment, which finds its presentation in a specific analytical expression, and its stability is determined by "constant" coefficients when the established values of the parameters "constantly", manifested analytical expressions, reflecting the pattern the process of self-organization and its accessible universality in the generation of the subsequent variability of self-organizing systems as a set of autonomous units interacting with each other.

In all cases, it was a question of the qualitative organization of this process without taking into account the potential energy-mass exchange necessary for its maintenance, which consisted in the simultaneous and sequential flow of various processes, which characterizes the qualitative feature of their organization. The simultaneous occurrence of the same processes reflects the strength of their severity (amplitude), and
Table 2

Ratios of the characteristic of static voltage with maximum effort, synergists and dynamics of the efforts of antagonists in providing a motor act and changing the value of pulsation of the range in different angular positions of the kinematic pair "thigh-shin". The data is selected from table 1

\begin{tabular}{c|cccccc}
\hline S & 120 & 120 & 120 & 120 & 120 & 120 \\
A & 100 & 90 & 80 & 60 & 40 & 30 \\
P & 20 & 30 & 40 & 60 & 80 & 90 \\
SV & 110 & 105 & 100 & 90 & 80 & 75 \\
\hline
\end{tabular}

successively the same processes, reflect the duration of their action.

This variability of possible combinations and "jointly proceeding processes" in a certain space with an appropriate density of their combination generates the stability of their occurrence, which is reflected by the amplitude-frequency dependence of their periodic repeatability, which has a strictly determined analytical apparatus reflecting the formation of this process.

When testing the material obtained, a method was used to estimate the athlete's energy potential to change the plyometric response of the $\partial \mathrm{F} / \partial \varphi$ indicator, which reflects the measure of static voltage during the development of fatigue during the current work and dynamic efforts, manifested in changes in the $\partial \mathrm{F} / \partial \mathrm{t}$ indicator, determining the speed of movement of the bio-kinematic links of the body and its common center mass.

The essence of it was to determine the magnitude of the change between the characteristic of the preceding signal to the measured next. From the entire video series, a set of identical signals was selected, which were located according to their size from the weakest to the strongest. Regarding them, a variation of outgoing and subsequent signals was noted; those that formed it, and those that formed it. In fact, this method, which was proposed by Galton in the method of "collective photography", was tested by Sheldon and, taking into account modern technical advances, in a modified version of its application, our own are used in scientific research carried out at Kharkiv State Academy of physical culture [22; 23].

All the calculations described were carried out in real time. The final signal processing was represented in the form of a graphical expression of a nomogram of two combined coordinate grids rotated relative to each other at an angle of $45^{\circ}$. The first rectangular grid represents the vertical (ordinate) change in energy potential in its maximum manifestation in a controlled individual. Horizontal (abscissa) there were changes in its minimal manifestation. The values of the boundaries of the pulsations were taken from the video series, which determined the range of pulsations in the change in the energy potential of the controlled individual.

The second rectangular grid represented by the ordinate value the current value of the pulsation energy potential when the controlled motor activity, and the abscissa represents the magnitude of the static voltage determined by changes in conducted performance plyometric control. The static voltage scale (abscissa in the second coordinate grid) in the first coordinate grid is the bisector of the angle of this coordinate grid.

The general picture of the observed interdependent processes, reflected in the indicative semantic space with the measure introduced in fractions of sigmal values, is presented 


\section{SLOBOZANS'KIJ NAUKOVO-SPORTIVNIJ VISNIK}

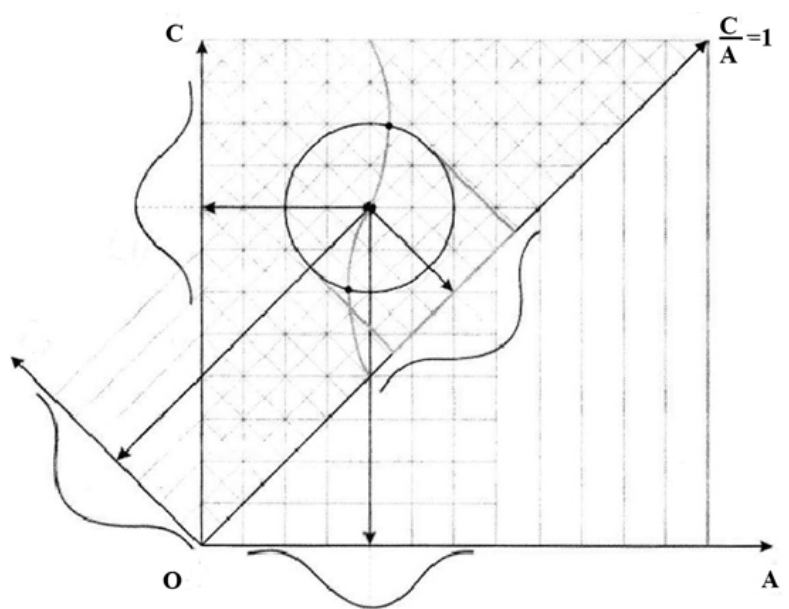

Fig. 1. The pattern of movement of the common point of the indicator of the energy potential ripple in its orderly representation in the indicative semantic space with its arbitrary manifestation in the potential naturally occurring process of a single combat fighter: $S$ - reflects the value of synergetic efforts in the relationship of potential with its antagonist $A$ in providing equal static voltage represented by all relations, when $S /(A=1)$, as the coefficient $\alpha$ of constant relations of static voltage, which is the diagonal of the coordinate system $\mathrm{S} ; \mathrm{A}$. The orthogonal to this diagonal is the coordinate axis of the pulsation of the coefficient $S /(A=1)$ and this diagonal itself constitutes a space that has a single origin with the space $S$; $A$ is rotated by an angle $\alpha=45^{\circ}$. The zone of joint intersection of these spaces is an area in which the interaction of a common point is reflected, which unites the interaction of all 4 parameters. Its movement generates an analytic regularity reflecting the interdependence of the behavior of that point. in Figure 1.

This method of monitoring and current analysis of the data obtained can be used in any kind of sports and professional activities.

The limiting complexity of the widespread use of this method is the technique used to provide it, which includes appropriate video equipment, computer equipment, appropriate software and specialists in its operation, which will later constitute the field of scientific and practical support for the training of high-ranking athletes.

\section{Conclusions / Discussion}

Based on the use of modern technical video equipment and computer equipment with appropriate programs for processing video sequences of performed movements and on the basis of established regularities of the flow of biodynamic characteristics in performing competitive movements of martial artists, a method of remote contactless monitoring of its current state has been developed.

Observing results obtained allow us to estimate the most energy-loss athletes in motor activity pursued controlled duel structure, whereby the tactical possible to determine the behavior of the athlete.

In the training process, the use of this method of monitoring the athlete's state allows for mastering the most economical techniques for performing difficult-coordinated actions, and when analyzing the "opponent" equipment, establish his weakest positions in the conduct of the fight.

Further development of this direction will be connected with its wider practical implementation.

Conflict of interests. The authors declare that no conflict of interest. Financing sources. This article didn't get the financial support from the state, public or commercial organization.

\section{References}

1. Yefremenko, A.M. (2014), "Influence of the complex of means of restoration of efficiency on operational and current functional condition of sprinters", Moloda sportyvna nauka Ukrainy, No. 1, pp. 67-72 (in Ukr.)

2. Druz, V.A., Omelchenko, M.V. \& Omelchenko, D.A. (2015), "Fundamentals of sprint technique", Slobozans 'kij naukovo-sportivnij visnik, No. 47, pp. 41-45. (in Russ.)

3. Van Sin Na. (2012), Sovershenstvovanie tehniki vyipolneniya sorevnovatelnyih uprazhneniy kvalifitsirovannyih sportsmenov $v$ pauerliftinge : dis. kand. nauk fiz.vosp. $i$ sporta [Improving the technique of performing competitive exercises of qualified athletes in powerlifting: PhD dis.], KSAPC, Kharkiv, 210 p. (in Russ.)

4. Artemeva, G.P., Pugach, Ya.I. \& Druz, V.A. (2014), Problema adaptatsii v strukture nauchnyih issledovaniy sistemyi olimpiyskogo obrazovaniya [The Problem of Adaptation in the Structure of Scientific Research on the System of Olympic Education], KSAPC, Kharkiv. (in Russ.)

5. Halashko, M.N. (2016), Vykorystannia morfofunktsiunalnykh pokaznykiv dlia prohnozuvannia uspishnosti sportyvnoi diialnosti armrestleriv: avtoref. dys. kand.nauk z fiz. vykhovannia ta sportu [Morphofunctional Indicators for Predicting Successful Sports Activities Armrestlers: $\mathrm{PhD}$ thesis abstract], Kharkiv, 22 p. (in Russ.)

6. Puhach, Ya.I. (2013), "Osnovnyie polozheniya postroeniya semanticheskogo prostranstva dlya uporyadochennogo predstavleniya rezultatov issledovaniya", Materialyi IX Mezhdunarodnoy nauchno-prakticheskoy konferentsii "B'deschego oprosyi otsveta na naukata", P. 39 , Sofiya, pp. 5-13. (in Russ.)

7. Yefremenko, A.M. (2015), "Complex p_dkhid to the power of each year's celebrated sprinter", Moloda sportyvna nauka Ukrainy, No. 1(19), pp. 82-86. (in Russ.)

8. Druz, V. et al. (2016), "Kinematic characteristics of a sprinting technique and morphofunctional structures of its providing", Journal of Education, Health and sport, Vol. 6(11), pp. 271-280. (in Russ.) Russ.)

9. Voronov, A.A. (1979), Ustoychivost, upravlyaemost, nablyudaemost [Stability, controllability, observability], Nauka, Moscow. (in

10. Anohin, P.K. (1973), Printsipialnyie voprosyi obschey teorii funktsionalnyih sistem. Printsipyi sistemnoy organizatsii funktsii [Principal Issues of the General Theory of Functional Systems. Principles of system organization of the function], Nauka, Moscow. (in Russ.)

11. Zade, L. (1974), Osnovyi novogo podhoda $k$ analizu slozhnyih sistem protsessov prinyatiya resheniy [Fundamentals of the new approach to the analysis of complex systems of decision-making processes], Znanie, Moscow. (in Russ.)

12. Bertalanffy, L. (1960), Problems of life; an evaluation of modern biological and scientific thought, Hoper Torctbooks, New York.

13. Haken, G. (1985), Sinergetika ierarhiy neustochivostey $v$ samoorganizuyuschihsya sistemah $i$ ustroystvah [Synergetics of hierarchies of instabilities in self-organizing systems and devices], Mir, Moscow. (in Russ.)

14. Samsonkin, V.N. (1997), Teoreticheskie osnovyi avtomatizirovannogo kontrolya chelovecheskogo faktora v cheloveko-mashinnyih sistemah na zheleznodorozhnom transporte: dis. dokt. teh. nauk [Theoretical Foundations of the Automated Control of the Human Factor in Man-Machine Systems in Railway Transport], Kharkiv, 440 p. (in Russ.)

Puhach, Y., Druz, V., Yefremenko, A., Revenko, V., Galashko, M. Shutieiev, V., Nizhevskaya, T. \& Miroshnichenko, V. (2019), "Modern methods of monitoring and assessing the current status of athletes-combatants in real time", Слобожанський науковоспортивн
3.010
Puhach, Y., Druz, V., Yefremenko, A., Revenko, V., Galashko, M., Shutieiev, V., Nizhevskaya, T. \& Miroshnichenko, V. (2019) "Modern methods of monitoring and assessing the current status of athletes-combatants in real time", Slobozans 'kij naukovosportivnij visnik, No. 3(71), pp. 54-60, doi:10.15391/snsv.2019-
3.010 


\section{СЛОБОЖАНСЬКИЙ НАУКОВО-СПОРТИВНИЙ ВІСНИК}

15. Samsonkin, V.N., Druz, V.A. \& Fedorovich, E.S. (2010), Modelirovanie v samoorganizuyuschih sistemah [Modeling in self-organizing systems], Donetsk. (in Russ.)

16. Zade, L. (1976), Ponyatiya lingvisticheskoy peremennoy i ego primenenie k prinyatiyu resheniya [The concepts of a linguistic variable and its application to decision making], Mir, Moscow. (in Russ.)

17. Sepp, E.I. (1959), Istoriya razvitiya nervnoy sistemyi pozvonochnyih [History of the development of the nervous system of vertebrates], Medgiz, Moscow. (in Russ.)

18. Sarkisov, M. (1972), Ocherki po strukturnyim osnovam gomeostaza [Essays on the structural bases of homeostasis], Meditsina, Moscow. (in Russ.)

19. Menshov, A.I. \& Ryilskiy, G.I. (1976), Chelovek v sisteme upravleniya letatelnyimi apparatami (ergonomika) [Man in the aircraft control system (ergonomics)], Mashinostroenie, Moscow. (in Russ.)

20. Puhach, Ya.I., Sokolova, T.E. \& Efremenko, A.N. (2017), "The use of modern technical advances to develop new methods for studying adaptation processes in order to improve the technology for training highly qualified athletes", Aktualnyie nauchnyie issledovaniya $v$ sovremennom mire, Iss. 12(32), Part 5, pp. 45-53. (in Russ.)

21. Azhippo, A.Yu., Puhach, Ya.I., Pyatisotskaya, S.S., Zhernovnikova, Ya.V. \& Druz, V.A. (2015), Ontologiya teorii postroeniya i otsenki urovnya fizicheskogo razvitiya i fizicheskogo sostoyaniya (monografiya) [Ontology of the theory of construction and assessment of the level of physical development and physical condition], KSAPC, Kharkiv. (in Russ.)

22. Haken, H. (1983), Synergetics. An introduction, 3rd ed., Springer, Berlin, Heidelberg, New York.

23. Bertalanfffy, L. (1950), "The theory of Open System in Physics and Biology", Science, 13 January, No. 111, pp. $23-29$.

24. Ladeh, L.A. (1973), "Outline of a New Approach to the Analysis of Complex System and Decision Processes", IEEE Trans on System, Man, and Cybern., Vol. SM-3, No.1, January.

Received: 14.05.2019.

Published: 30.06.2019.

Анотація. Ярославна Пугач, Валерій Друзь, Андрій Єфременко, Валерій Ревенко, Микола Галашко, В'ячеслав Шутєєв, Тетяна Ніжевська, Валерій Мірошниченко. Сучасні методи моніторингу та оцінки поточного стану спортсменівєдиноборців у реальному часі. Мета: встановити найбільш ефективні методи контролю і оцінки поточного стану спортсменів, і на підставі цього розробити методи дистанційного контролю за поточним станом єдиноборців в реальному масштабі часу в процесі ведення поєдинку. Матеріали і методи: у проведених дослідженнях використовувалися відеоматеріали змагальних поєдинків спортсменів, що беруть участь в чемпіонатах України, чемпіонатах Світу, Олімпійських іграх. Використовувані методи: "швидкісна відеозйомка" біомеханічний аналіз кінематичних переміщень загального центру маси спортсмена і окремих біокінематичних ланок тіла з подальшим визначенням динамічних зусиль, що забезпечують їх переміщення, а також статистичного напруження, що визначає доступне йому забезпечення цих зусиль. Результати: на підставі вищевикладеного для оцінки поточного функціонального стану єдиноборців при проведенні поєдинку була використана закономірність зміни характеристики $\partial F / \partial \varphi$ у пліометричному режимі ї̈ прояву в рухах у період реакцій з опорою. Це відбивається на характері статичної напруги, яка спостерігається в змінах її величини і тривалості протікання. Процес дистанційного спостереження здійснювався спеціальною відеокамерою і відповідною програмою обробки відеоряду рухів спортсмена, виконаних в реальному масштабі часу. Систематизація рухової діяльності спортсмена протягом усього поєдинку полягає в поділі його рухових дій на безконтактне переміщення і контактну взаємодію. У часовому ряді руху спортсмена здійснювалася безперервна оцінка зміни величини $\partial F / \partial \varphi$ і на ї̈ тлі велася оцінка значення $\partial F / \partial t$, що дозволило встановити взаємовідношення варіації величини статичного напруження і динамічного зусилля, що визначає дії спортсмена. Висновки: використання сучасних технічних засобів відеореєстрації і комп'ютерної техніки з відповідними програмами обробки відеоряду спортивних рухів, а також на підставі встановлених закономірностей протікання біодинамічних зусиль змагальних рухів єдиноборців відкривають широкі можливості розробки методів дистанційного безконтактного контролю за поточним станом спортсменів.

Ключові слова: семантичні простори, біомеханічний аналіз, динамічне зусилля.

Аннотация. Ярославна Пугач, Валерий Друзь, Андрей Ефременко, Валерий Ревенко, Николай Галашко, Вячеслав Шутеев, Татьяна Нижевская, Валерий Мирошниченко. Современные методы мониторинга и оценки текущего состояния спортсменов-единоборцев в режиме реального времени. Цель: установить наиболее эффективные методы контроля и оценки текущего состояния спортсменов, и на основании этого разработать методы дистанционного контроля за текущим состоянием единоборцев, осуществляемые в реальном масштабе времени в процессе ведения поединка. Материал и методы: в проводимых исследованиях использовались видеоматериалы соревновательных поединков спортсменов, участвующих в чемпионатах Украины, мировых первенствах, Олимпийских играх. Используемые методы: "скоростная видеосъемка, "биомеханический анализ кинематических перемещений общего центра массы спортсмена и отдельных биокинематических звеньев тела с последующим определением динамических усилий, обеспечивающих их перемещение, а также статистического напряжения, определяющего доступное ему обеспечение этих усилий. Результаты и выводы: использование современных технических видеорегистрирующих средств и компьютерной техники с соответствующими программами обработки видеоряда выполняемых движений и на основании установленных закономерностей протекания биодинамических усилий соревновательных движений единоборцев открывают широкие возможности разработки методов дистанционного бесконтактного контроля за текущим состоянием спортсменов.

Ключевые слова: семантические пространства, биомеханический анализ, динамическое усилие.

\section{Information about the Authors}

Пугач Ярославна Ігорівна: к. фіз. вих.; Харківська державна академія фізичної культури: вул. Клочківська 99, м. Харків, 61058, Україна.

Пугач Ярославна Игоревна: к. физ. восп.; Харьковская государственная академия физической культуры: ул. Клочковская 99, г. Харьков, 61058, Украина.

Yaroslavna Puhach: PhD (physical education and sport); Kharkiv State Academy of Physical Culture: Klochkivska str. 99, Kharkiv, 61058, Ukraine.

ORCID.ORG/0000-0001-5460-772X

E-mail: sanadruz@gmail.com

Друзь Валерій Анатолійович: д. б. н., професор; Харківська державна академія фізичної культури: вул Клочківська 99, м. Харків, 61058, Україна.

Друзь Валерий Анатольевич: д. б. н., профессор; Харьковская государственная академия физической культуры: ул. Клочковская 99, г. Харьков, 61058, Украина.

Valeriy Druz: Doctor of Science (Biology), Professor; Kharkiv State Academy of Physical Culture: Klochkivska 99, Kharkiv, 61058,

Puhach, Y., Druz, V., Yefremenko, A., Revenko, V., Galashko, M., Shutieiev, V., Nizhevskaya, T. \& Miroshnichenko, V. (2019), "Modern methods of monitoring and assessing the current status of athletes-combatants in real time", Слобожанський науковоСпортивний вісник, № 3(71), С. 54-60, doi:10.15391/snsv.2019-
3.010
Puhach, Y., Druz, V., Yefremenko, A., Revenko, V., Galashko, M., Shutieiev, V., Nizhevskaya, T. \& Miroshnichenko, V. (2019), "Modern methods of monitoring and assessing the current status of athletes-combatants in real time", Slobozans 'kij naukovosportivnij visnik, No. 3(71), pp. 54-60, doi:10.15391/snsv.2019-
3.010 


\section{SLOBOZANS'KIJ NAUKOVO-SPORTIVNIJ VISNIK}

Ukraine.

ORCID.ORG/0000-0002-4628-6791

E-mail: valeriidruz@gmail.com

Єфременко Андрій Миколайович: к. фіз. вих.; Харківська державна академія фізичної культури: Україна, м. Харків, вул. Клочківська, 99.

Ефременко Андрей Николаевич: к. физ. восп.; Харьковская государственная академия физической культуры: ул. Клочковская 99, г. Харьков, 61058, Украина.

Andriy Yefremenko: PhD (Physical Education and Sport); Kharkiv State Academy of Physical Culture: Klochkovskaya str. 99, Kharkiv, 61058, Ukraine.

ORCID.ORG/0000-0003-0924-0281

E-mail: ukrnac@ukr.net

Ревенко Валерій Олександрович: к. п. н., доцент; Харківський національний університет внутрішніх справ, 61080, Україна, м. Харків, пр-т Л. Ландау, 27

Ревенко Валерий Александрович: к. п. н., доцент; Харьковский национальный университет внутренних дел, 61080, Украина, г. Харьков, пр-т Льва Ландау, 27

Valeriy Revenko: PhD (Pedagogical Science), docent; Kharkiv National University of Internal Affairs, L. Landau avenue, 27, Kharkiv, 61080, Ukraine.

ORCID.ORG/0000-0002-3003-3538

E-mail: revphd@gmail.com

Галашко Микола Іванович: Харківська державна академія фізичної кульутри: вул. Клочківська, 99. м.Харків, 61058, Україна.

Галашко Николай Иванович: Харьковская государственная академия физической культуры: ул. Клочковская, 99, г. Харьков, Украина

Mykola Galashko: Kharkiv State Academy of Physical Culture, Klochkovskaya 99, Kharkiv, 61058, Ukraine

ORCID.ORG/0000-0001-5278-9806;

E-mail: kaf-va-b@ukr.net

Шутєєв Вячеслав Вадимович: к. фіз. вих.; Харківська державна академія фізичної кульутри, вул. Клочківська, 99. м.Харків, 61058, Україна.

Шутеев Вячеслав Вадимович: к. виз. восп.; Харьковская государственная академия физической культуры, ул. Клочковская, 99, г. Харьков, Украина.

Vjacheslav Shutieiev: PhD (Physical Education and Sport); Kharkiv State Academy of Physical Culture, Klochkovskaya 99, Kharkiv, 61058, Ukraine.

ORCID.ORG/0000-0002-5262-2085

E-mail: shutey1971@mail.ru

Ніжевська Тетяна Вікторівна: к. п. н.; Харківський націона льний педагогі чний університе тім. Григорія Сковороди, вул. Валентинівська, 2, Харків, 61000, Україна.

Нижевская Татьяна Викторовна: к. п. н.; Харьковский национальный университетим. Григория Сковороды, ул. Валентиновская, 2, Харьков, 61000, Украина.

Tetyana Nizhevskaya: PhD (Pedagogical Science); H. S. Skovoroda Kharkiv National Pedagogical University, Valentynivska st., 2, Kharkiv, 61000, Ukraine.

ORCID.ORG/0000-0003-2151-2067

E-mail: nymbis@gmail.com

Мірошніченко Валерій Іванович: к. п. н.; Харківський націона льний педагогі чний університе тім. Григорія Сковороди, вул. Валентинівська, 2, Харків, 61000, Україна

Мирошниченко Валерий Иванович: к. П. н.; Харьковский национальный университет им. Григория Сковороды, ул. Валентиновская, 2, Харьков, 61000, Украина

Valery Miroshnichenko: PhD(Pedagogical Science), docent; H. S. Skovoroda Kharkiv National Pedagogical University, Valentynivska st., 2, Kharkiv, 61000, Ukraine

ORCID.ORG/0000-0003-2362-9226

E-mail: mvtet@ukr.net

Puhach, Y., Druz, V., Yefremenko, A., Revenko, V., Galashko, M. Shutieiev, V., Nizhevskaya, T. \& Miroshnichenko, V. (2019), "Modern methods of monitoring and assessing the current status of athletes-combatants in real time", Слобожанський науковоспорт "Modern methods of monitoring and assessing the current status of athletes-combatants in real time", Slobozans 'kij naukovo sportivnij visnik, No. 3(71), pp. 54-60, doi:10.15391/snsv.2019
3.010 